\title{
鈍化き裂まわりの非定常な水素拡散-弾塑性連成解析*
}

\author{
小 竹 広 和*1, 松 本 龍 介*2 $^{* 2}$ \\ 武富 紳 也*2, 宮 崎 則 幸*3

\section{Transient Hydrogen Diffusion-Elastoplastic Coupling Analysis near a Blunting Crack Tip}

\author{
Hirokazu KOTAKE*4, Ryosuke MATSUMOTO, \\ Shinya TAKETOMI and Noriyuki MIYAZAKI \\ ${ }^{* 4}$ Graduated School of Engineering, Kyoto University, \\ Yoshida Honmachi, Sakyo-ku, Kyoto-shi, Kyoto, 606-8501 Japan
}

\begin{abstract}
The effect of hydrogen on the metals is known as hydrogen embrittlement, which affects the structural integrity of a hydrogen energy system. Hydrogen atoms near a crack tip play an important role in the hydrogen embrittlement. In the present paper, we developed a computer program for an transient hydrogen diffusion-elastoplastic coupling analysis by combining an in-house finite element program for hydrogen diffusion analysis with a general purpose finite element computer program for stress analysis. In the hydrogen diffusion equation, we consider both the hydrogen concentration at the normal intersticial lattice sites and that at the trap sites, and also take account of hydrogen diffusion flux due to hydrostatic stress. We use a hypothesis that the hydrogen absorbed in the metal affects the yield stress of the metal. Therefore, the hydrogen diffusion problem is coupled with the elastoplastic stress problem. Using the computer program developed in the present study, we performed the transient hydrogen diffusion-elastoplastic coupling analysis of a cracked plate made of a bcc-metal, and obtained the hydrogen concentration, hydrostatic stress and plastic strain near the crack tip. In the present paper, we discuss the effects of the initial hydrogen concentration, the boundary condition of hydrogen on the free surface and the loading frequency. An important finding obtained from the present study is the fact that the hydrogen concentration near the crack tip depends greatly on the loading frequency. The fact indicates that the fatigue lives of the components in a hydrogen system depend not only on the number of loading cycles but also on the loading time.
\end{abstract}

Key Words : Numerical Analysis, Finite Element Method, Coupling Problem, Hydrogen Embrittlement, Hydrogen Diffusion, Blunting Crack Tip, Coupled Effect Parameter, Frequency Effect

\section{1. 緒言}

近年，水素の安定的な利用技術を確立することを目 的として多くの研究が行われている(1) (6). 機械工学分 野では，燃料電池などで水素を用いる際の構造材料の 水素脆化をはじめとした力学特性の変化等, 水素が関 わる諸現象のメカニズム解明が課題となっている.

水素脆化と一概に言っても，その全貌は明らかになっ ていない，長年の研究より，脆化機構としていくつか の説が唱えられ, 相変態説 ${ }^{(7)}$, 面圧説 ${ }^{(8)}{ }^{(9)}$, 凝集力低 下 (Decohesion) 説 ${ }^{(10)}$ などがある. それに加え, 水素の

* 原稿受付 2007 年 4 月 5 日.

*1 学生員, 京都大学大学院工学研究科(画 606-8501 京都市左 京区吉田本町).

*2 正員, 京都大学大学院工学研究科, 産総研外来研究員.

*3 正員, フェロー, 京都大学大学院工学研究科, 産総研外来研 究員.

E-mail : kotake@solid.me.kyoto-u.ac.jp
存在によって転位が局在化し，材料の破壊勒性が低下 する HELP(Hydrogen Enhanced Localized Plasticity) 説 (7) (11)が近年多くの支持を得ている. また, 機械構造材 料が破壊する主要因として疲労き裂進展による破壊が あり，それに水素脆化が大きく影響することも報告さ れている(12). 水素脆化のメカニズムを解明するために は, 塑性変形を伴うき裂周りのマクロな水素分布やそ の配位状態の詳細を知ることが重要である.

き裂まわりの水素拡散解析例として, Sofronis $ら^{(13)}$ によって考案された水素拡散解析手法がある。また，

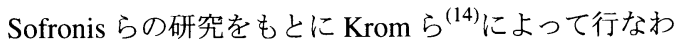
れた有限要素法解析ソフトMarc 中に水素拡散方程式 を組み込んだ非定常水素拡散解析手法は, 汎用性の面 からも非常に有用である.しかし，Kromらの研究では Marc を用いて行なった弾塑性解析から静水忘力や塑 
性ひずみなどを引数として水素拡散方程式を解いただ けであり，金属中に水素が存在することによる材料特 性の変化は考慮されていない, その後, Sofronis ら ${ }^{(15)}$ やLiang ら ${ }^{(3)(16)}$ は独自に開発した弾塑性-水素拡散連 成解析プログラム中で水素が金属の弾性および塑性に 与える影響を考慮した解析を行なっているが，こちら では論文の目的や構成式の特性から, 非定常な水素拡 散解析ができていない. また, 水素が金属の弾性に及

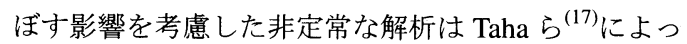
て行なわれたが，水素が金属の塑性に影響を及ぼすこ とを考慮した非定常解析は未だ行なわれていない。

本研究では Krom らの非定常水素拡散解析をもとに, Marcによるき裂周りの弾塑性解析の中に水素拡散方 程式と水素による降伏応力の変化式を組み込むことで 水素と弾塑性の連成解析を可能にする. また, これを 用いてき裂開口過程での非定常水素濃度分布の変化を 考察する.

\section{2. 理 論}

2.1 水素拡散方程式 金属中での水素の存在状 態は大きく分けて, 結晶格子中に配位する格子間配位 (Normal Interstitial Lattice Sites) と, 転位や空孔といっ た格子久陥に配位する欠陥配位 (Trapping Sites) の 2 種 類に分類される.

格子間配位の水素原子数 $C_{\text {Lattice }}$ (以下 $C_{\mathrm{L}}$ ) は,

$$
C_{\mathrm{L}}=\theta_{\mathrm{L}} N_{\mathrm{L}}
$$

$\left(\theta_{\mathrm{L}}\right.$ :水素が格子間配位を占有する比率, $N_{\mathrm{L}}$ :単位体積あ たりの格子間配位数) と表せる. 欠陥配位の水素原子 数 $C_{\mathrm{Trap}}\left(\right.$ 以下 $C_{\mathrm{T}}$ ) は,

$$
C_{\mathrm{T}}=\theta_{\mathrm{T}} N_{\mathrm{T}}
$$

$\left(\theta_{\mathrm{T}}\right.$ : 水素が欠皕配位を占有する比率, $N_{\mathrm{T}}$ : 単位体積あた りの久陷密度) と表せる(13). Kumnick $ら^{(18)}$ により, 純 鉄における $N_{\mathrm{T}}$ と塑性ひずみ $\varepsilon_{\mathrm{p}}$ の関係が,

$$
\log _{10} N_{\mathrm{T}}=23.26-2.33 \exp \left(-5.5 \varepsilon_{\mathrm{p}}\right)
$$

と実験的に得られている.

また，格子間配位水素の周辺に塑性ひずみによって 欠陥が生じたとき, 水素が欠陥配位状態に変化する 現象を Oriani ${ }^{(19)}$ は平衡定数を $K_{\mathrm{T}}$ とした濃度平衡と して,

$$
K_{\mathrm{T}}=\exp \left(-\frac{W_{\mathrm{B}}}{R T}\right)=\frac{1-\theta_{\mathrm{L}}}{\theta_{\mathrm{L}}} \cdot \frac{\theta_{\mathrm{T}}}{1-\theta_{\mathrm{T}}}
$$

$\left(W_{\mathrm{B}}\right.$ : 㫿配位との結合エネルギ, $R$ :ガス定数, $T$ : 絶対 温度) とした. 上式より $C_{\mathrm{T}}$ は $C_{\mathrm{L}}$ の関数として,

$$
C_{\mathrm{T}}=\frac{N_{\mathrm{T}} K_{\mathrm{T}} C_{\mathrm{L}}}{K_{\mathrm{T}} C_{\mathrm{L}}+N_{\mathrm{L}}}
$$

と得られる ( $\theta_{\mathrm{L}} \ll 1$ のとき) そして後に水素が材料特 性に与える効果を評価するために全体水素量 $C$ と全体 水素濃度 $c$ を,

$$
c=\frac{C}{N_{\mathrm{L}}}=\frac{C_{\mathrm{L}}+C_{\mathrm{T}}}{N_{\mathrm{L}}}
$$

と考える ${ }^{(15)}$.

水素の拡散は保存則から,

$$
\frac{\partial}{\partial t} \int_{V}\left\{C_{\mathrm{L}}+C_{\mathrm{T}}\right\} \mathrm{d} V+\int_{S} \mathrm{~J} \cdot \mathrm{nd} S=0
$$

と書ける.J は水素拡散流束であり，

$$
\mathrm{J}=-D_{\mathrm{L}} \nabla C_{\mathrm{L}}+\frac{D_{\mathrm{L}} C_{\mathrm{L}} V_{\mathrm{H}}}{R T} \nabla \sigma_{\mathrm{h}}
$$

$\left(D_{\mathrm{L}}\right.$ :格子間配位水素拡散係数, $V_{\mathrm{H}}$ : 水素部分モル体積, $\sigma_{\mathrm{h}}\left(=\sigma_{i i} / 3\right)$ :静水応力) である. 通常の拡散問題とは異 なり静水応力に依存した右辺第 2 項の拡散流束項が重 要になる.

式 (2), (4) より， $C_{\mathrm{T}}$ を $C_{\mathrm{L}}$ の関数として考えると $C_{\mathrm{T}}$ の時間微分は,

$$
\begin{aligned}
\frac{\partial C_{\mathrm{T}}}{\partial t} & =\frac{\partial C_{\mathrm{T}}}{\partial C_{\mathrm{L}}} \frac{\partial C_{\mathrm{L}}}{\partial t}+\frac{\partial C_{\mathrm{T}}}{\partial N_{\mathrm{T}}} \frac{\partial N_{\mathrm{T}}}{\partial \varepsilon_{\mathrm{p}}} \frac{\partial \varepsilon_{\mathrm{p}}}{\partial t} \\
& =\frac{C_{\mathrm{T}}\left(1-\theta_{\mathrm{T}}\right)}{C_{\mathrm{L}}} \frac{\partial C_{\mathrm{L}}}{\partial t}+\theta_{\mathrm{T}} \frac{\partial N_{\mathrm{T}}}{\partial \varepsilon_{\mathrm{p}}} \frac{\partial \varepsilon_{\mathrm{p}}}{\partial t}
\end{aligned}
$$

である ${ }^{(14)}$. 式 (8)，(9) を式(7)に代入し，ガウスの発 散定理を用いると，

$$
\begin{gathered}
\int_{V}\left\{D^{*} \frac{\partial C_{\mathrm{L}}}{\partial t}-\nabla \cdot\left(D_{\mathrm{L}} \nabla C_{\mathrm{L}}\right)+\nabla \cdot\left(\frac{D_{\mathrm{L}} C_{\mathrm{L}} V_{\mathrm{H}}}{R T} \nabla \sigma_{\mathrm{h}}\right)\right. \\
\left.+\theta_{\mathrm{T}} \frac{\partial N_{\mathrm{T}}}{\partial \varepsilon_{\mathrm{p}}} \frac{\partial \varepsilon_{\mathrm{p}}}{\partial t}\right\} \mathrm{d} V=0
\end{gathered}
$$

となる.ここで有効拡散係数 $D^{*}$ として，

$$
D^{*}=\frac{C_{\mathrm{L}}+C_{\mathrm{T}}\left(1-\theta_{\mathrm{T}}\right)}{C_{\mathrm{L}}}
$$

とおいた。

2.2 数值解析への導入 ガラーキン法を用い, 変 数 $C_{\mathrm{L}}$ について任意の変分 $\delta C_{\mathrm{L}}$ を考えると式 (10) は,

$$
\begin{gathered}
\int_{V}\left\{\delta C_{\mathrm{L}} D^{*} \frac{\partial C_{\mathrm{L}}}{\partial t}+\nabla \delta C_{\mathrm{L}} D_{\mathrm{L}} \nabla C_{\mathrm{L}}-\nabla \delta C_{\mathrm{L}} \frac{D_{\mathrm{L}} C_{\mathrm{L}} V_{\mathrm{H}}}{R T} \nabla \sigma_{\mathrm{h}}\right. \\
\left.+\delta C_{\mathrm{L}} \theta_{\mathrm{T}} \frac{\partial N_{\mathrm{T}}}{\partial \varepsilon_{\mathrm{p}}} \frac{\partial \varepsilon_{\mathrm{p}}}{\partial t}\right\} \mathrm{d} V+\int_{S} \delta C_{\mathrm{L}} \phi \mathrm{d} S=0
\end{gathered}
$$

となる. 上式の導出過程でガウスの発散定理を再び用 い, 表面流束 $\phi$ を,

$$
\phi=\mathrm{J} \cdot \mathrm{n}=\left(-D_{\mathrm{L}} \nabla C_{\mathrm{L}}+\frac{D_{\mathrm{L}} C_{\mathrm{L}} V_{\mathrm{H}}}{R T} \nabla \sigma_{\mathrm{h}}\right) \cdot \mathrm{n}
$$

と定義した. 
式 (12) の各変数に有限要素法における形状関数 $[N]$ および $[B](=\nabla[N])$ を用いて

$$
\begin{array}{ll}
C_{\mathrm{L}}=[N]\left\{C_{\mathrm{L}}\right\} & \delta C_{\mathrm{L}}=[N]\left\{\delta C_{\mathrm{L}}\right\} \\
\dot{C}_{\mathrm{L}}=[N]\left\{\dot{C_{\mathrm{L}}}\right\} & \nabla C_{\mathrm{L}}=[B]\left\{C_{\mathrm{L}}\right\}
\end{array}
$$

とそれぞれ離散化すれば， $\delta C_{\mathrm{L}}$ は任意の変分であるこ とより, 各項を,

$$
\begin{aligned}
{[M] } & =\int_{V}[N]^{\mathrm{T}} D^{*}[N] \mathrm{d} V \\
{\left[K_{1}\right] } & =\int_{V}[B]^{T} D_{\mathrm{L}}[B] \mathrm{d} V \\
{\left[K_{2}\right] } & =-\int_{V}[B]^{T} \frac{D_{\mathrm{L}} V_{\mathrm{H}}}{R T}[B]\left[\sigma_{\mathrm{h}}\right][N] \mathrm{d} V \\
\left\{F_{1}\right\} & =-\int_{S}[N]^{T} \phi \mathrm{d} S \\
\left\{F_{2}\right\} & =-\int_{V}[N]^{T} \theta_{\mathrm{T}} \frac{\partial N_{\mathrm{T}}}{\partial \varepsilon_{\mathrm{p}}} \frac{\partial \varepsilon_{\mathrm{p}}}{\partial t} \mathrm{~d} V
\end{aligned}
$$

とすれば,

$$
[M]\left\{\dot{C_{\mathrm{L}}}\right\}+\left(\left[K_{1}\right]+\left[K_{2}\right]\right)\left\{C_{\mathrm{L}}\right\}=\left\{F_{1}\right\}+\left\{F_{2}\right\}
$$

という格子間配位水素量 $C_{\mathrm{L}}$ の時間に関する微分方程 式が得られる.

ところが式 (19) は，時間微分を含んだままである. よって水素濃度の時間微分を後退差分法

$$
\left\{\dot{C_{\mathrm{L}}}\right\} \approx \frac{1}{\Delta t}\left(\left\{C_{\mathrm{L}}\right\}_{t+\Delta t}-\left\{C_{\mathrm{L}}\right\}_{t}\right)
$$

を用いて離散化する.

プログラム中で拡散方程式を解く際には,

$$
[\alpha]\left\{C_{\mathrm{L}}\right\}_{t+\Delta t}=\{\beta\}
$$

という形にまとめて計算を行なう.このとき, 以下に 述べる方法により左辺のマトリックス $[\alpha]$ は対称マト リックスであるとして, 対称成分のみを計算する手法 を用いている.

式 (19) を水素濃度分布 $\left\{C_{\mathrm{L}}\right\}_{t+\Delta t}$ のみを未知数とし て解くため, 時間ステップを十分に細かく取ることで, $\left\{F_{1}\right\}_{t+\Delta t}=\left\{F_{1}\right\}_{t}, \quad\left\{F_{2}\right\}_{t+\Delta t}=\left\{F_{2}\right\}_{t}$ と1 ステップ前の 值で近似する. また, $\left[K_{2}\right]$ は非対称マトリックスである ので, 同じく $\left\{C_{\mathrm{L}}\right\}_{t}$ の係数と考えて右辺に移項し $\{\boldsymbol{\beta}\}$ の成分として扱えば,

$$
\begin{aligned}
\left(\frac{1}{\Delta t}\right. & {\left.[M]_{t}+\left[K_{1}\right]\right)\left\{C_{\mathrm{L}}\right\}_{t+\Delta t} } \\
& =\left(\frac{1}{\Delta t}[M]_{t}-\left[K_{2}\right]_{t}\right)\left\{C_{\mathrm{L}}\right\}_{t}+\left\{F_{1}\right\}_{t}+\left\{F_{2}\right\}_{t}
\end{aligned}
$$

と時間的にも離散化される ${ }^{(14)}$.

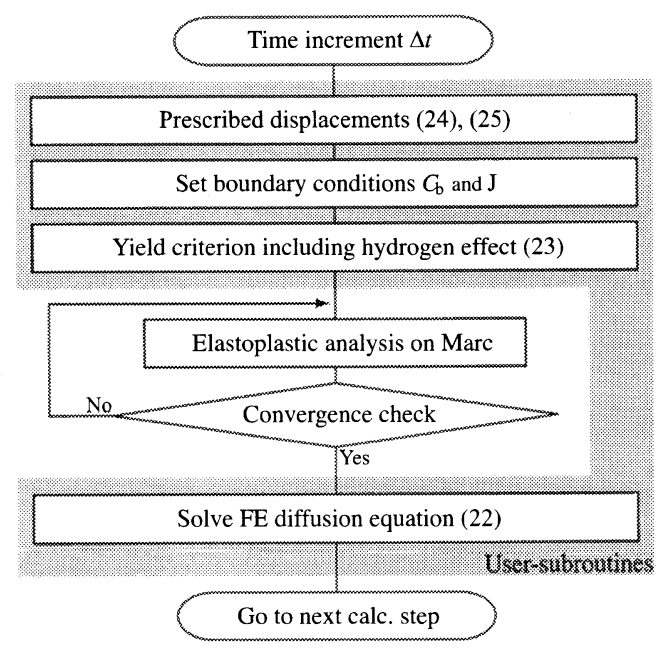

Fig. 1 Flowchart of FEM analysis

$2 \cdot 3$ 弾塑性構成式 有限要素法を用いてき裂開 口のような大変形解析を行うときは, updated Lagrange 型の定式化を行う。本解析では Prandtl-Reuss の構成則 を用い, 応力速度に Cauchy 応力の Jaumann 速度 $\sigma_{i j}$ を用いる ${ }^{(20)}$.

2.4 降伏条件式材料の降伏挙動は, von Mises の降伏条件にしたがうとする. Sofronis ら ${ }^{(15)}$ は，材料 中に水素が存在すると流動応力 $\sigma_{\mathrm{Y}}$ が,

$$
\sigma_{\mathrm{Y}}\left(\varepsilon_{\mathrm{p}}, c\right)=(\xi \cdot c+1) \sigma_{0} \cdot\left(1+\frac{\varepsilon_{\mathrm{p}}}{\varepsilon_{0}}\right)^{n}
$$

$\left(\sigma_{0}\right.$ : 初期降伏応力, $\varepsilon_{0}$ : 初期降伏ひずみ, $n$ :加工硬化係 数) と表されるとした. ここで $\xi$ を連成効果パラメー 夕と呼び, 水素の存在によって降伏応力が変化する度 合いを表し，水素の影響を考える指標とする，材料に より， $\boldsymbol{\xi}<0$ すなわち水素によって軟化するものと， $\xi>0$ すなわち硬化するものがある.

2.5 MSC. Marcへの組み込み 本解析では, 汎 用性を考えて有限要素法解析ソフトMarc の弾塑性大 変形解析機能を用いる. Marcにより, 水素拡散方程 式を解くときに必要な静水応力や塑性ひずみなどを計 算し，それを引数として用いて計算を行う.

実際には，Marc 中で任意のサブプログラムを実行 できるユーザサブルーチンを利用し，そこに水素拡散 方程式 (22), 連成効果式 (23) および, 後に述べる変位 境界条件を与える式 (24)(25) を組み込むことで水素応力連成解析を実行する。このとき弾塑性解析では, 各節点の相対変位が繰り返し前後差 $0.1 \%$ 以下になる まで繰り返し計算を行なう，本論文で示した全ての連 成問題に対して，このような収束判定基準で収束解が 
得られた。また，収束に必要な繰り返し数は10 回程 度であった。図 1 に組み込んだ水素拡散解析部分の計 算の流れを示す

2.6 解析モデル 基礎的な材料に対する知見を 得るため, 材料には純鉄を想定する. 解析系の温度 $T$ は常に一定の $300[\mathrm{~K}]$ とすれば，結晶は bcc 構造をと る. bcc 構造の金属は fcc 構造や hcp 構造の金属に比 べ水素拡散係数が 3 桁から 4 林大きいことが特徴であ $ろ^{(21)}$. 物性値を表 1 に示す ${ }^{(18)(22)(23)}$.

鈍化き裂モデルとして, 半径 $R$ が $90[\mathrm{~mm}]$, 初期き 裂半径 $b_{0} / 2$ が $5[\mu \mathrm{m}]$ の X 軸二次元対称モデルを想定 し, その上半分を解析する. 要素メッシュとして 4 節 点の平面ひずみ一次要素と低減積分スキームを用い, 角度方向に $0<\theta<\pi / 2$ で 12 等分, $\pi / 2<\theta<\pi$ で 8 等分の計 20 分割, 半径方向に節点間隔を 1.29 倍ずつ 倍加させつつ 40 分割して 859 節点 799 要素に分割す る. 小規模降伏理論にもとづき，

$$
\begin{aligned}
& u_{\mathrm{X}}=K_{I} \frac{1+v}{E} \sqrt{\frac{R}{2 \pi}} \cos \frac{\theta}{2}(3-4 v-\cos \theta) \\
& u_{\mathrm{Y}}=K_{I} \frac{1+v}{E} \sqrt{\frac{R}{2 \pi}} \sin \frac{\theta}{2}(3-4 v-\cos \theta)
\end{aligned}
$$

という式で規定される強制変位をモデル外周部に与え ることで，モード I 支配の応力拡大係数 $K_{\mathrm{I}}$ を加える. 純鉄に関するき裂進展試験例は少ないので, 機械の水 素使用部位に構造材として期待されているフェライト 系ステンレス鋼 SUS405 での水素導入き裂進展実験 ${ }^{(12)}$ を参考に, 最大応力拡大係数はき裂進展量が十分小さ い $K_{\mathrm{I}}=40[\mathrm{MPa} \sqrt{\mathrm{m}}]$ とする．負荷は，任意の負荷時間 $t_{\text {Load }}$ 後に $K_{\mathrm{I}}$ に達する様に直線的に増加させる，時間 方向の計算ステップは $t_{\text {Load }}$ を 100 分割した. X 軸上 にある各節点の $\mathrm{Y}$ 方向変位は拘束する。図 2 にき裂 まわりの拡大図を示す. 初期水素濃度は全節点で一定 の $C_{\mathrm{L} 0}=$ const. とし，外縁部およびき裂表面の水素の 流出入を解析条件として変化させる.

最後に, X方向長さを規格化するためにき裂開口量 $b$ を定義する．負荷後のき裂先端を基準としてX軸か ら $135^{\circ}$ の方向に線を伸ばし, き裂面と交わった位置 の $\mathrm{Y}$ 座標の 2 倍をき裂開口量 $b$ とする.

\section{3. 解 析}

\section{1 計算精度の確認 まず本論文で開発した計算} プログラムの精度を, Krom の解析条件 (応力拡大係数 $K_{\mathrm{I}}=89.2[\mathrm{MPa}]$, 初期水素濃度 $C_{\mathrm{L} 0}=2.08 \times 10^{21}\left[\mathrm{~m}^{-3}\right]$, 連成効果パラメータ $\xi=0$, き裂先端からの水素の流 出人なし $(\mathrm{J} \cdot \mathrm{n}=0)$, 負荷時間 $\left.t_{\mathrm{Load}}=130[\mathrm{~s}]\right)^{(14)}$ で解析 を行なって検証する.
Table 1 Material properties

\begin{tabular}{l|l}
\hline Density $\rho\left[\mathrm{m}^{-3}\right]$ & $7.87 \times 10^{3}$ \\
\hline Young's modulus $E[\mathrm{~Pa}]$ & $207 \times 10^{9}$ \\
\hline Poisson's ratio $v$ & 0.3 \\
\hline Initial yield stress $\sigma_{0}[\mathrm{~Pa}]$ & $250 \times 10^{6}$ \\
\hline Work hardening exponent $n$ & 0.2 \\
\hline Lattice sites per unit volume $N_{\mathrm{L}}\left[\mathrm{m}^{-3}\right]$ & $5.1 \times 10^{29}$ \\
\hline Lattice diffusivity $D_{\mathrm{L}}\left[\mathrm{m}^{2} / \mathrm{s}\right]$ & $1.27 \times 10^{-8}$ \\
\hline Partial molar volume $V_{\mathrm{H}}\left[\mathrm{m}^{3} / \mathrm{mol}\right]$ & $2.0 \times 10^{-6}$ \\
\hline Trap binding energy $W_{\mathrm{B}}[\mathrm{J} / \mathrm{mol}]$ & $-60 \times 10^{3}$ \\
\hline
\end{tabular}

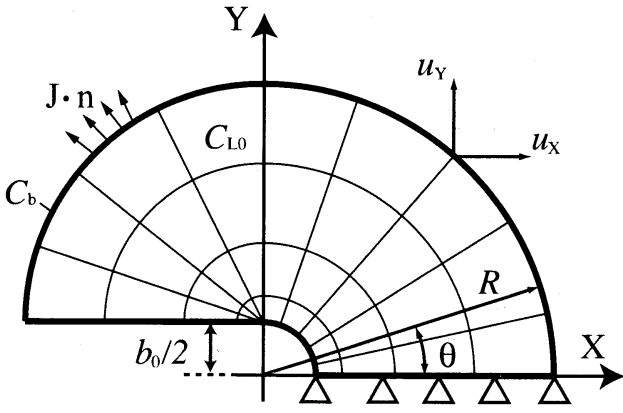

Fig. 2 Analysis model

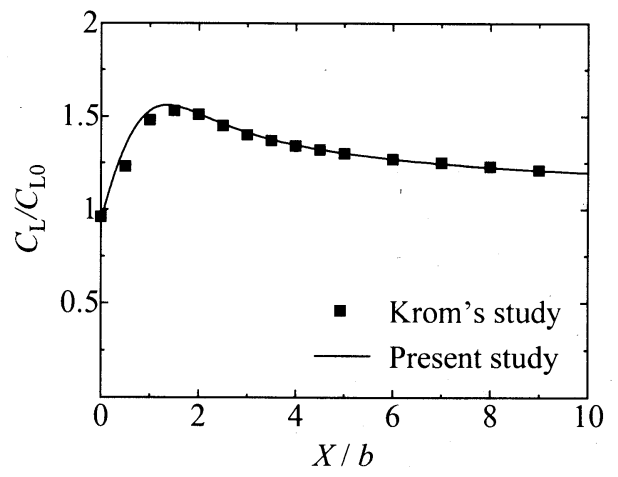

Fig. 3 Comparison of hydrogen concentration on present analysis result with Krom's study

図 3 にき裂前方 $(\theta=0)$ 方向での格子間配位水素 $C_{\mathrm{L}}$ をこのときの初期水素濃度によって規格化したものを 表す．実線が本解析プログラムでの結果，中黒四角が Krom での結果を示す.き裂前方方向いずれの場所に おいても誤差は $5 \%$ 以内に収まっている，き裂先端部 で結果のずれが大きくなっているが，Krom は論文中 で計算の収束条件等に触れていないこと，ここも誤差 は $5 \%$ 以内であることより，これは許容範囲内の誤差 であると考え，本解析プログラムは十分な精度を持っ ているといえる. 


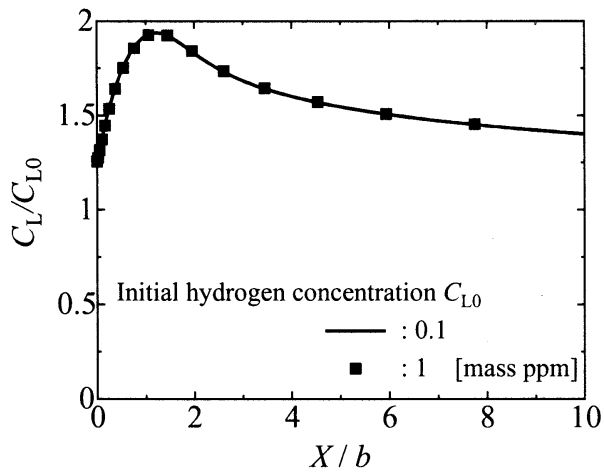

(a) Hydrogen concentration at lattice site

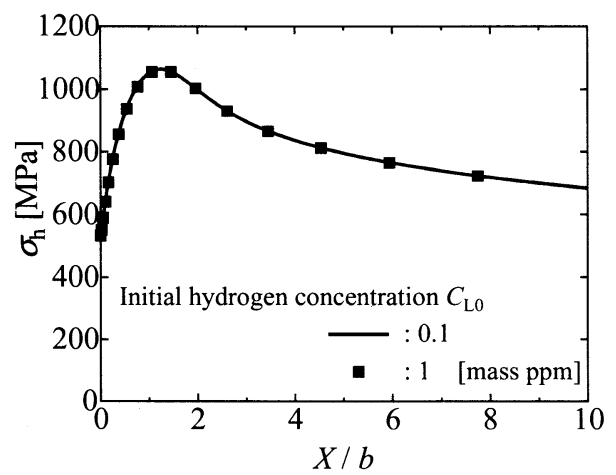

(c) Hydrostatic stress

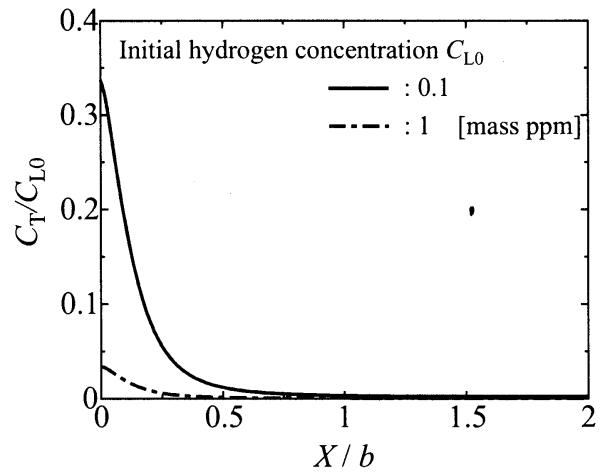

(b) Hydrogen concentration at trap site

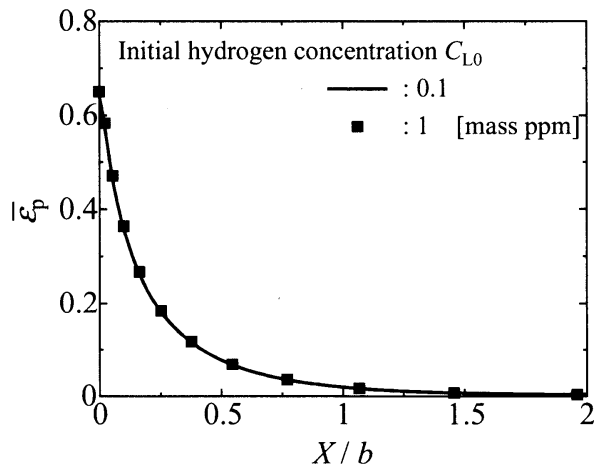

(d) Equivalent plastic strain

Fig. 4 Distributions of various physical properties $(t=100[\mathrm{~s}])$

3.2 初期濃度による水素拡散挙動の変化 以上 のき裂モデルを用いて，き裂開口が起こるときのき裂 まわりの水素拡散解析を行なう. 本節ではまず, 初期 水素濃度 $C_{\mathrm{L} 0}$ の違いによって生じる水素拡散挙動の差 異を考察する。

初期水素濃度について, き裂開口応力拡大係数 $K_{\mathrm{I}}$ を 決定したときと同じくSUS405 での実験条件を参考に， (1)外部から水素を全く充填しないときの SUS405 中の 通常水素濃度 (0.1 [mass ppm]) と, (2)SUS405 に水素 チャージを行なって充填された濃度 (1 [mass ppm]) が き裂まわりに均一に分布したとする 2 つの初期濃度条 件を考える. 本節では水素が材料の弾塑性に与える影 響を考慮しない $(\xi=0)$. また, 表面境界条件として 水素の流出入を考えない $(\mathrm{J} \cdot \mathrm{n}=0)$ ものとし, 負荷時 間 $t_{\text {Load }}$ は $100[\mathrm{~s}]$ とする.

図 4(a) に初期水素濃度を(1)，(2)にとったときのき裂 前方 $(\theta=0)$ 方向での格子間配位水素 $C_{\mathrm{L}}$ をそれぞれ の初期水素濃度 $C_{\mathrm{L} 0}$ によって規格化したもの, 図 4(b) に同じく初期水素濃度を(1)，(2)としたときの欠陥配位 水素 $C_{\mathrm{T}}$ の分布を各初期水素濃度で規格化したものを
示す. 図 4(c) に静水応力分布, 図 4(d) に相当塑性ひず み分布を示す. 結果はいずれも負荷時間後 $(t=100[\mathrm{~s}])$ の值である.

格子間配位水素やそれに大きな影響を与える静水応 力は, 水素が材料に与える影響を無視しているので初 期水素濃度が異なっても分布は完全に一致し, き裂前 方, 特に $X / b \simeq 1$ 付近で高い值を取る. 初期水素濃度 に対する集中度 $\left(C_{\mathrm{L}} / C_{\mathrm{L} 0}\right)$ も, ほぼ同様の変化傾向を 示寸. 陌配位水素は, 強変形が生じるき裂先端付近 でのみ高くなっていることがわかる. しかし欠陥配位 水素量は, 強変形が生じているにも関わらずそれぞれ の初期濃度に対して集中度 $\left(C_{\mathrm{T}} / C_{\mathrm{L} 0}\right)$ が大きく異なっ ている.これは, 平衡関係式 (5) に示される欠陥配位 水素に対する格子間配位水素の比 $\left(C_{\mathrm{T}} / C_{\mathrm{L}}\right)$ が，格子間 配位水素の濃度が少ないときは高い比で存在するのに 対し, 格子間配位水素濃度が増えるにつれて低い比で しか存在しなくなるという特徴のためである.

よって，水素が充填されているような材料について， その拡散は格子間配位水素によって支配的に進行する といえる．また，全体水素濃度 $c($ 式(6)) とそれを用い 


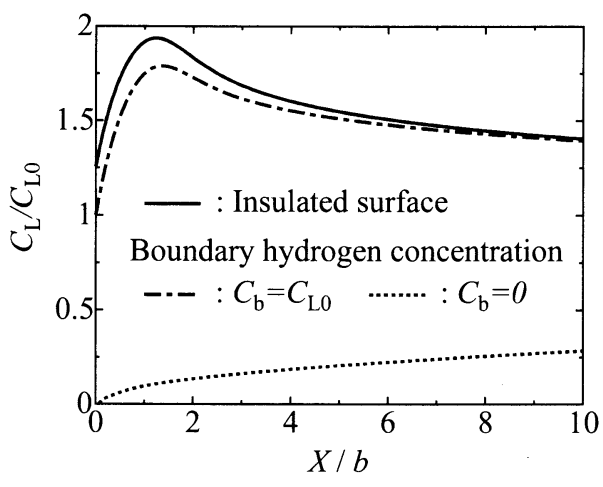

Fig. 5 Distributions of hydrogen concentration at lattice site for various boundary conditions $(t=100[\mathrm{~s}])$

た水素連成効果の定義式 (23) でも全体水素量の大部分 を格子間配位水素が占めるため，き裂先端で欠陷配位 水素が降伏応力に対して及ぼす影響は小さいといえる.

3.3 表面境界条件の影響水素がき裂表面や外 周部で流出入する現象を想定して解析を行ない，その 影響を明らかにする．き裂表面及びモデル外周部の境 界条件として (i) 水素の流出入がない $(\mathrm{J} \cdot \mathrm{n}=0)$ 状態, (ii) 水素ガス雰囲気下での実験を想定し水素濃度が常に 一定 $\left(C_{\mathrm{b}}=C_{\mathrm{L} 0}\right)$ を保つように流出入が起こる状態，(iii) 電気チャージ後に大気中で実験を行なうことを想定し き裂まわりに存在する水素はすべて流出する $\left(C_{\mathrm{b}}=0\right)$ 状態, という3 つの境界条件を考える. 初期水素濃度 $C_{\mathrm{L} 0}$ は 1 [mass ppm] とした. ここでも水素が材料に与 える影響は考えず $(\xi=0)$, 負荷時間 $t_{\text {Load }}$ は $100[\mathrm{~s}]$ と する.

図 5 に境界条件 (i), (ii), (iii) でそれぞれ行なった解 析結果のうち, 負荷時間後 $(t=100[\mathrm{~s}])$ の格子間配位水 素 $C_{\mathrm{L}}$ の分布を示す. 実線が条件 (i) での解析結果, 一 点鎖線が条件 (ii) での解析結果を示す.どちらの結果 においてもき裂前方 (特に $X / b \simeq 1$ ) で水素濃度が高く なる傾向は同様であるが，境界条件を (i) とした結果 の方がき裂先端でより水素濃度が高くなっている．試 験条件 (ii) の場合は，き裂表面の水素濃度が常に $C_{\mathrm{L} 0}$ に保たれるため, 水素の流出が起きて水素濃度が低下 していると考えられる.ただし， $X / b \simeq 10$ にかけて 水素濃度がほぼ同一に近づいていっており, 流出の影 響はき裂の近傍のみに生ずるといえる。

また，もしき裂表面に水素が一切存在しない(iii)の 条件を仮定すると，図 5 の点線が示すように水素は急 速にき裂外部に流出してしまうと考えられ，水素が材 料に与える影響を考察するには不適切な条件となる.
3.4 連成効果パラメータによる相互連成解析こ こまで, 応力やひずみが急激に増加する弾塑性変形に おける水素拡散について解析を行なった。 しかし本来 は水素の存在が弾塑性に対して影響を与える水素脆化 も起こっているはずであり，この相互効果がどのよう になるかを知ることこそ重要である.

よって, 水素の存在によって降伏応力が変化したと き，水素分布をはじめ応力分布や塑性領域がどのよう に変化するのかを解析する．式 (23) に示した水素濃 度の影響を受ける降伏条件式を用いる. 降伏応力変化 率を定める連成効果パラメータ $\xi$ 用いているが，こ れは材料定数であり実験によって求めなければならな い. ここでは，降伏応力低下による影響を考察すべく， 水素が降伏応力に対して影響を与えない $\xi=0$, 初期 水素濃度 $C_{L 0}=1\left[\right.$ mass ppm] に対して降伏応力 $\sigma_{\mathrm{Y}}$ が $10 \%$ および $20 \%$ 低下する $\xi=-10000,-20000$ を 考えることで，応力と水素の連成効果がどのように作 用するかを明らかにする，き裂まわりの水素流出入境 界条件として, 水素濃度が常に一定 $\left(C_{\mathrm{b}}=C_{\mathrm{L} 0}\right)$ を保つ ように流出入が起こる状態を考える. 負荷時間 $t_{\text {Load }}$ は 100[s] とする.

図 6(a) に連成効果パラメータを $\xi=0,-10000$, -20000 としたときの格子間配位水素 $C_{\mathrm{L}}$ をそれぞれ の初期水素濃度 $C_{\mathrm{L} 0}$ によって規格化したもの, 図 6(b) に同じ条件で欠陥配位水素 $C_{\mathrm{T}}$ の分布を各初期水素濃 度で規格化したものを示す. 図 6(c) に静水応力分布, 図 6(d) に相当塑性ひずみ分布を示す. 結果はいずれも 負荷時間後 $(t=100[\mathrm{~s}])$ の值である.

静水応力 $\sigma_{\mathrm{h}}$ が水素による軟化の影響が大きくなる のに従って低下している. また, 静水応力に依存して いる格子間配位水素 $C_{\mathrm{L}}$ も徐々に低下している. 一方, 欠陥配位水素 $C_{\mathrm{T}}$ は降伏応力が減少するにつれて増加 傾向にある.この值に支配的な影響を及ぼす相当塑性 ひずみ $\bar{\varepsilon}_{\mathrm{p}}$ にいて着目してみると, 連成効果パラメー タが小さいほどき裂先端で高い值を持ち, 強変形が生 じていることがわかる。これより，連成効果パラメー 夕の值を小さくすることによって降伏応力が低下する と，それに伴って塑性降伏領域が広がり，そこに配位 する欠陥配位水素量が増加していると言える.

3.5 負荷周波数による水素拡散挙動の変化 前 節までの検討により, 水素拡散と弾塑性が相互に影響 し合う解析とその傾向について知ることができた.こ こで，実験結果 ${ }^{(2)}{ }^{(12)}$ や式 (22) から明らかなように，水 素分布はその拡散時間に大きく依存する非定常な変化 をすると考えられる．よって最後に，様々な負荷時間 を取ったときの水素拡散の変化を調心゙，その時間依存 


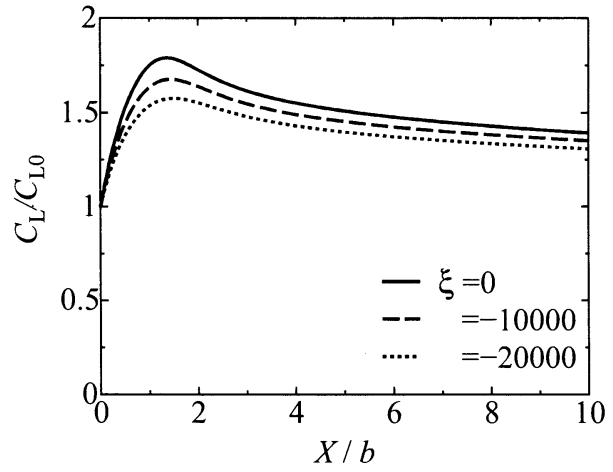

(a) Hydrogen concentration at lattice site

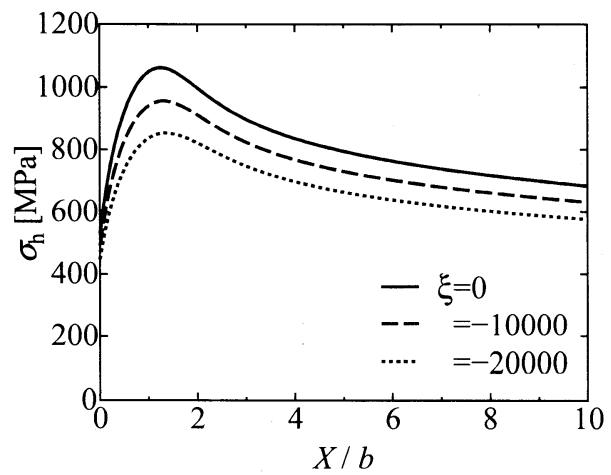

(c) Hydrostatic stress

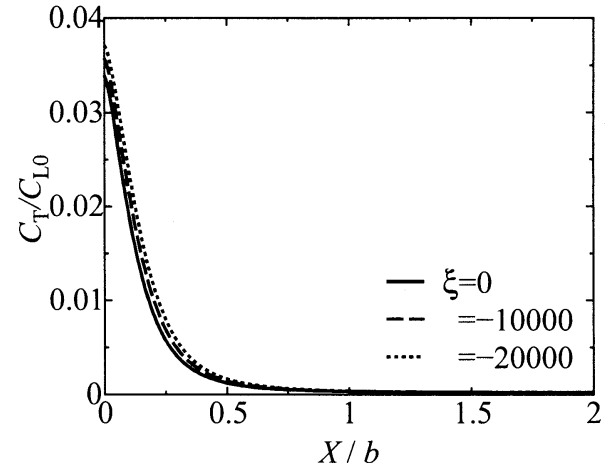

(b) Hydrogen concentration at trap site

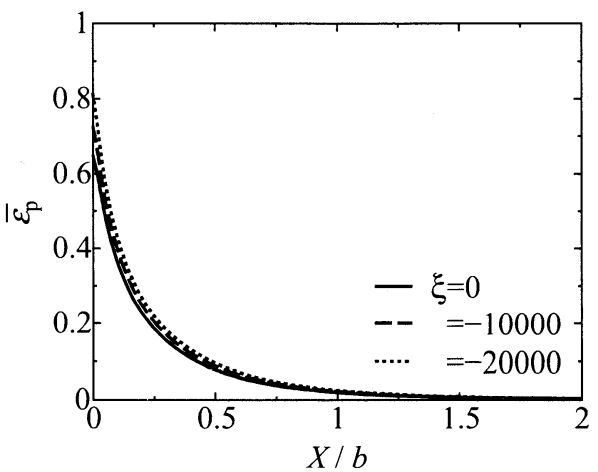

(d) Equivalent plastic strain

Fig. 6 Distributions of various physical properties $(t=100[\mathrm{~s}])$

性を考察する.

ここまでの解析結果をもとに，応力-水素拡散連 成効果も考慮して降伏応力が初期水素濃度 $C_{\mathrm{L} 0}=$ 1 [mass ppm] に対して $10 \%$ 低下するとする. 実際の使 用環境や疲労試験では水素雾囲気中, 大気中問わず表 面からの水素流出入が想定されるので，き裂表面は水 素濃度一定 $\left(C_{\mathrm{b}}=C_{\mathrm{L} 0}\right)$ に保つ. 本解析と疲労き裂進展 試験などの繰り返し負荷状態とを対応付けるため, 負 荷時間 $t_{\text {Load }}$ の 2 倍の逆数を試験周波数 $f$ とする. つま り，負荷時間が $100[\mathrm{~s}]$ ならば負荷周波数で $0.005[\mathrm{~Hz}]$ に対応する. 実際の負荷周波数は $0.005,0.05,0.5,5$, $50[\mathrm{~Hz}]$ とし, 一回負荷した後 $(t=1 /(2 f)[\mathrm{s}])$ の解析結 果について考察する. 格子間配位水素 $C_{\mathrm{L}}$ について解 析結果を図 7(a) に示す. 負荷周波数が高くなるにつれ て濃度分布が一定に近くなり, 濃度も低くなっていく. これは高周波数のときには一回の負荷が行なわれるま での時間が短いため，水素が拡散するのに十分な時間 が得られないためと考えられる. 周波数が低くなると 十分な拡散時間が得られて最大值が高くなっていき, それと同時にその位置が $X / b \simeq 1.5$ まで移動していく.
しかし，50[Hz] と $5[\mathrm{~Hz}]$ の拡散間隔に比べて $0.05[\mathrm{~Hz}]$ と $0.005[\mathrm{~Hz}]$ の間では明らかに水素濃度の増加幅が小 さくなっている. これより，仮に周波数を無限に低く したとしても，ある值以下の速さでは水素集中が飽和 に達する定常水素濃度が存在すると考えられる。

負荷周波数を $500[\mathrm{~Hz}]$ から $1 / 10$ 倍づつ低くしていく ときの分布中の静水応力集中部での最高水素濃度を図 7(b) に示す. 負荷周波数を低くしていくと $5 \times 10^{-3}[\mathrm{~Hz}]$ 以下で最高水素濃度がほぼ定常に達することがわかる. 欠陥配位水素量の周波数ごとの分布を図 7(c) に示す が，これらは格子間配位水素分布とは異なり，周波数 の変化による影響がほとんど見られない，つまり，水 素拡散時閒を変化させて解析や試験を行ったとき, 支 配的に影響されるのは格子間配位水素量である.また, この水素分布が定常に達する周波数は，拡散係数の小 さい材料や低降伏応力の材料では，より低周波数側に 移ると考えられる.

実際の疲労き裂試験では比較的早い負荷周波数で試 験を行うことが多いが，図 7(b) が示すように周波数の 違いによる水素集中特性の差異を考慮しなければ，実 


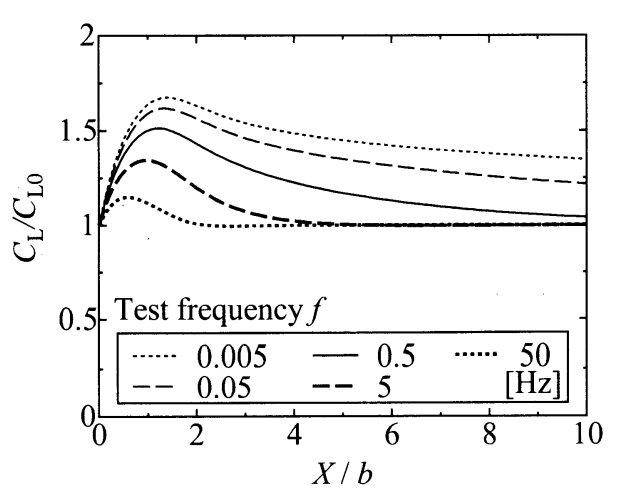

(a) Distribution of hydrogen concentration at lattice site

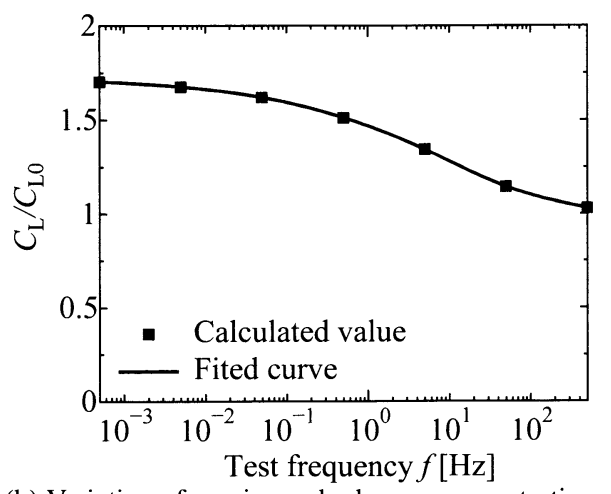

(b) Variation of maximum hydrogen concentration

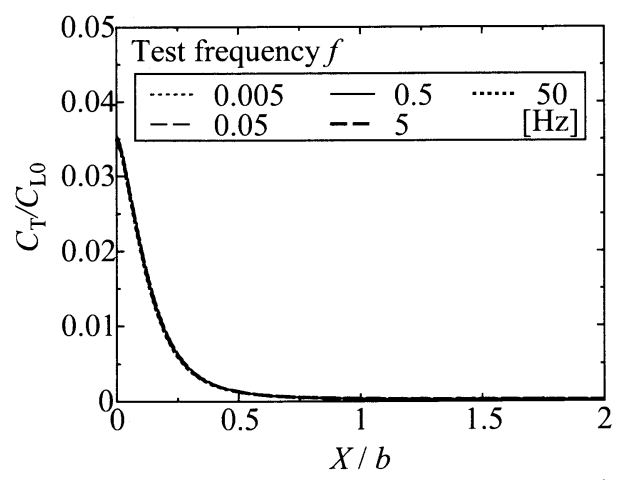

(c) Distributions of hydrogen concentration at trap site

Fig. 7 Frequency effect

構造物の破壊勒性值は試験結果と大きく異なることが 予想される. また, 周波数が低くなると拡散濃度が上 昇傾向にあることからも破壊が予想より早まると考え られ, 大変危険である. よって, 実際の使用周波数に 対して十分な注意が必要である.

\section{4. 結言}

汎用弾塑性変形解析プログラムに応力-非定常水素 拡散連成解析機能を組み込み, 種々の条件を考えて解 析を行なうことで以下の知見を得た。

1. 水素が材料に十分充填された場合，その拡散には 格子間配位水素が支配的な影響を及ぼしていると いえる.

2. 水素分布が降伏応力に影響を与える相互連成効果 を考えると, 静水応力や水素分布は降伏応力の低 下に伴って低下し, 塑性ひずみや塑性降伏領域は 增加する.

3. 現実問題として重要な水素拡散の非定常性につい て, 負荷速度を変化させた解析を行なうと, き裂 開口が起こるとき負荷の初期段階から試験周波数 によって水素分布に大きな差異が現れる.これよ り，高周波数で行なわれた疲労試験結果と実際の 使用対象材料の負荷条件に対して, 負荷周波数へ の十分な注意が必要である.

\section{謝 辞}

本研究成果の一部は, NEDO 技術開発機構の水素材 料先端科学基礎研究事業の一環として行なったもので ある.また，公益信託 ENEOS 水素基金の援助も受け た. 感謝してここに記する.

\section{文献}

(1) Murakami, Y., The effect of hydrogen on fatigue properties of metals used for fuel cell system, International Journal of Fracture, Vol.138, No.1-4 (2006), pp.167-195.

(2) Uyama, H., Mine, Y., Murakami, Y., Nakashima, M., Morishige, K., Effects of Hydrogen Charge on Cyclic Stress-Strain Properties and Fatigue Behaviour of Carbon Steels, Journal of the Society of Materials Science, Japan, Vol.54, No. 12 (2005), pp.1225-1230.

(3) Liang, Y., Sofronis, P., Dodds, R.H., Jr., Interaction of hydrogen with crack-tip plasticity: effects of constraint on void growth, Materials science and engineering, Vol.A366, No.2 (2004), pp.397-411.

(4) Yokobori, A.T., Jr., Nemoto, T., Satoh, K., Yamada, $\mathrm{T}$., Numerical analysis on hyrogen diffusion and concentration in solid with emission around the crack tip, Engineering Fracture Mechanics, Vol.55, No.1 (1996), pp.47-60.

(5) Yokobori, A.T., Jr., Chinda, Y., Nemoto, T., Satoh, K., Yamada, T., The characteristics of hydrogen diffusion and concentration around a crack tip concerned with hydrogen embrittlement, Corrosion Science, Vol.44, No.3 (2002), pp.407-424.

(6) Krom, A.H.M., Bakker, A., Koers, R.W.J., Modelling hydrogen-induced cracking in steel using a coupled diffusion stress finite element analysis, International Journal of Pressure Vessels and Piping, Vol.72, No.2 (1997), pp.139-147. 
(7) Turnbull, A., Modeling of environment assisted cracking, Corrosion science, Vol.34, No.6 (1993), pp.921-960.

(8) Zapffe, C.A., Neumann bands and the planar-pressure theory of hydrogen embrittlement, Journal of the Iron and Steel Institute, Vol.154, No.2 (1946), p.123.

(9) Tetelman, A.S., Robertson, W. D., Mecanism of hydrogen embrittlement observed in iron-silicon single crystals, Transactions of the Metallurgical Society of AIME, Vol.224, No.4 (1962), p.775.

(10) Oriani, R.A., Josephic, P.H., Equilibrium aspects of hydrogen-induced cracking of steels, Acta Metallurgica, Vol.22, No.9 (1974), pp.1065-1074.

(11) Beachem, C.D., New Model for Hydrogen-Assisted Cracking (Hydrogen "Embrittlement"), Metallugical Transactions, Vol.3, No.2 (1972), pp.437-451.

(12) Kanezaki, T., Narazaki C., Mine Y., Matsuoka S., Murakami Y., Effect of Hydrogen on Fatigue Crack Growth and Martensitic Transformation of Stainless Steels, Transaction of the Japan Society of Mechanical Engineers, Series A, Vol.72, No.11 (2006), pp.1717-1724.

(13) Sofronis, P., McMeeking, R.M., Numerical analysis of hydrogen near a blunting crack tip, Journal of the Mechanics and Physics of Solids, Vol.37, No.3 (1989), pp.317-350.

(14) Krom, A.H.M., Koers, R.W.J., Bakker, A., Hydrogen transport near a blunting crack tip, Journal of the Mechanics and Physics of Solids, Vol.47, No.4 (1999), pp.971-992.
(15) Sofronis, P., Liang, Y., Aravas, N., Hydrogen induced shear localization of the plastic flow in metalls and alloys, European Journal of Mechanics A/Solids, Vol.20, No.6 (2001), pp.857-872.

(16) Liang, Y., Sofronis, P., Aravas, N., "On the effect of hydrogen on plastic instabilities in metals", Acta Metallurgica, Vol.51, (2003), pp.2717-2730.

(17) Taha, A., Sofronis, P., "A micromechanics approach to the study of hydrogen transport and embrittlement", Engineering Fracture Mechanics, Vol.68, (2001), pp.803837.

(18) Kumnick, A.J., Johnson, H.H., Deep trapping states for hydrogen in deformed iron, Acta Metallurgica, Vol.28, No.1 (1980), pp.33-39.

(19) Oriani, R.A., The diffusion and trapping of hydrogen in steel, Acta Metallurgica, Vol.18, No.1 (1970), pp.147157.

(20) McMeeking, R.M., Rice, J.R., Finite-element formulations for problems of large elastic-plastic deformation, International Journal of Solids Structures, Vol.11, No.5 (1975), pp.601-616.

(21) Fukai, Y., Sugimoto, H., Diffusion of hydrogen in metals, Advances in Physics, Vol.34, No.2 (1985), pp.263-326.

(22) Branis, E.A., Brooks, G.B., Smithells metals reference book 7th edition, (1992), Buttersworths, London.

(23) Hirth, J.P., Effects of hydrogen on the properties of iron and steel, Metallurgical transactions A, Vol.11, No.6 (1980), pp.861-890. 